\title{
KONVERGENSI IFRS, KUALITAS AUDIT, DAN MANAJEMEN LABA
}

\author{
Fitri Ramadhani1), Theresia Woro Damayanti²)
}

Fakultas Ekonomika dan Bisnis Universitas Kristen Satya Wacana

J1 Diponegoro 52-60 Salatiga 50711 - Jawa Tengah

E-Mail: 232016078@student.uksw.edu

\author{
Akuntansi Bisnis dan \\ Manajemen (ABM), \\ Volume 27 \\ Nomor 1 \\ Halaman 1-19 \\ Bulan April, Tahun 2020 \\ ISSN 0854-4190 \\ E-ISSN 2685-3965
}

Informasi Artikel

Tanggal Masuk:

23 Februari 2020

Tanggal Revisi:

2 Maret 2020

Tanggal Diterima:

7 April 2020
The purpose of this study is to analyzed how the IFRS convergence influence earnings management with audit quality as a moderating variable. The study was conducted on manufacturing companies listed on the Indonesia Stock Exchange in the period 2008-2018 obtained using the purposive sampling method. The results of the study using panel data analysis showed that IFRS convergence negatively and significantly affected earnings management.This shows that the convergence of IFRS has an impact on the decline in earnings management practices. However, this study failed to prove audit quality as a moderating variable.

Keywords: IFRS convergence; earning Management; audit quality

\begin{abstract}
Abstrak
Studi ini bertujuan untuk menganalisis pengaruh dari konvergensi IFRS terhadap manajemen laba dengan kualitas audit sebagai variabel moderasi. Sampel dalam studi ini adalah perusahaan manufaktur yang terdaftar di Bursa Efek Indonesia periode 20082018 dengan menggunakan teknik purposive sampling method. Selanjutnya analisis dilakukan menggunakan regresi data panel, hasil studi menunjukkan bahwa konvergensi IFRS memiliki dampak untuk menurunkan praktek manajemen laba, namun studi ini gagal untuk membuktikan bahwa kualitas audit memoderasi pengaruh antara konvergensi IFRS terhadap manajemen laba.
\end{abstract}

Kata kunci: konvergensi IFRS, manajemen laba, kualitas audit 


\section{PENDAHULUAN}

Masalah yang terjadi terkait dengan pelaporan keuangan yaitu manajemen laba yang sudah marak dan mulai menjadi budaya perusahaan. Laporan keuangan perusahaan disusun dengan berpedoman pada standar akuntansi keuangan. Rohaeni \& Aryati (2012) menjelaskan bahwa laporan keuangan juga harus dapat dipahami oleh para pemakai secara keseluruhan, dalam dunia bisnis global standar pelaporan keuangan yang digunakan yaitu International Financial Reporting Standards (IFRS). IFRS merupakan standar yang digunakan sebagai standar akuntansi negara di dunia yang telah diterbitkan oleh International Accounting Standards Board (IASB). IFRS berguna untuk memudahkan bisnis lintas negara dan adopsi IFRS dimulai pada tiap negara di dunia. Adopsi IFRS secara mandatory akan mempercepat laju kualitas informasi akuntansi dan menurunkan manajemen laba dibandingkan saat sebelum mengadopsi IFRS (Chen, Tang, Jiang, \& Lin, 2010). Ikatan Akuntan Indoensia (IAI) menyusun PSAK yang harus terus memperbaiki standar karena bagian penting dari perbaikan manajemen laba yaitu dengan dampak yang terdapat dari standar akan mendukung pembentukan laporan keuangan yang berkualitas, karena praktik-praktik manajemen laba akan mampu dideteksi oleh Auditor yang tersertifikasi yang memiliki kualitas yang baik dan tinggi (Rusmin, 2010).

Manajemen laba tentunya akan menunjukan hasil audit laporan keuangan yang di audit oleh perusahaan Big 4 yang kualitasnya baik dibandingkan dengan perusahaan nonBig 4 (Kabir \& Laswad, 2011). Indonesia telah mengadopsi IFRS pada tanggal 1 Januari 2010 yang berlaku penuh pada tahun 2012. Terdapat tiga tahapan pengadosian IFRS di Indonesia, yang pertama tahap adopsi tahun 2008-2010, kedua tahap persiapan tahun 2011, dan yang ketiga tahap implementasi tahun 2012 (Nurhayanto, 2010). Konvergensi IFRS diduga berpengaruh negatif terhadap manajemen laba, yang berarti bahwa konvergensi IFRS menyebabkan penurunan manajemen laba setelah perusahaan menerapkan standar IFRS. Manajemen laba merupakan suatu sasaran yang digunakan manajer dalam mencapai tujuan dari laporan keuangan perusahaan secara objektif yang dimanfaatkan manajer dalam pemilihannya menurut kebijakan akuntansi (Luthan, 2016). Pemilihan metode akuntansi dalam penyesuaian dengan standar pelaporan baiknya sesuai dengan kondisi perusahaan untuk untuk meringankan kinerja manajer dalam melakukan manajemen laba. Cahyati (2010) mengungkapkan bahwa dalam peralihannya IFRS yang basisnya prinsip (principle based) akan berpengaruh terhadap penggunaan nilai wajar (fair value) dengan pengungkapaanya akan berdampak menurunkan manajemen laba.

Praktik dari tindakan dari manajemen laba telah menimbulkan permasalahan, kasus laporan keuangan yang ada Indonesia telah terjadi pada perusahaan PT Inovisi Infracom (INVS) yaitu perusahaan holding investasi infrastruktur bidang telekomunikasi. Laporan keuangan yang disampaikan oleh PT INVS dianggap fiktif dan terdapat kesalahan dalam penyajian laporan keuangannya, PT Bursa Efek Indonesia mengambil upaya untuk mendeteksi adanya salah saji pada pembayaran kas kepada karyawan dan dalam penerimaannya laporan keuangan PT INVS dalam praktik ini pembayaran gaji karyawan yang semula Rp 1,9 Triliun menjadi Rp 59 Miliar 
pada kuartal ketiga dan selalu mengalami perubahan nilai setiap merevisi laporan keuangan perusahaan tidak hanya itu, dalam praktik ini laba per saham perusahaan INVS terlihat lebih besar tidak seperti seharusnya.

Penelitian yang dilakukan oleh Santy \& Pontoh (2012) menunjukan bahwa adopsi IFRS tidak berpengaruh terhadap manajemen laba. Manajemen laba juga akan membatasi pergerakan kualitas informasi yang akan diberikan dengan adopsi IFRS(Dimitropoulos, Asteriou, Kousenidis \& Leventis, 2013), akan tetapi menurut Narendra \& Haryanto (2013) adopsi IFRS berpengaruh positif pada manajemen laba. Namun demikian, Handayani (2014) memberikan bukti empiris bahwa manajemen laba pada perusahaan manufaktur di Indonesia tidak memiliki pengaruh terhadap adopsi IFRS. Hasil penelitian lain juga mengungkapkan adanya hubungan yang positif dan signifikanf antara adopsi IFRS dengan manajemen laba atau dengan kata lain dengan adanya konvergensi IFRS perusahaan lebih mampu mengendalikan laporan keuangan dengan adanya batasan standar dan kualitas audit yang tersertifikasi dengan baik (Permata, Muslim \& Fauziati, 2015).

Kontroversi hasil studi sebelumnya mengenai dampak konvergensi IFRS terhadap manajemen laba membuka celah penelitian dimungkinkan adanya variabel moderasi kualitas audit. Dalam meningkatkan kualitas informasi akuntansi tidak hanya melihat standar yang diterapkan akan tetapi juga berhubungan dengan manajer dan auditor yang jelas sebagai pihak yang akan mengidentifikasi dan mendeteksi kecurangan pada laporan keuangan. De Angelo (1981) memberikan pendapat mengenai kualitas audit yang berhubungan dengan ukuran perusahaan bahwa perusahaan yang besar akan menyajikan laporan keuangan yang lebih berkualitas. Penelitian yang menilai kualitas audit kemampuan yang dimiliki auditor dalam melakukan audit laporan keuangan yang baik akan membantu menjelaskan kualitas audit dan menurunkan tingkat manajemen laba dengan demikian adanya standar IFRS dengan kualitas audit akan menurunkan tingkat praktik manajemen laba (Rohaeni \& Aryati, 2012). Perusahaan auditf yang besar akan mampu memberikan signal penyelewengan perusahaan atau kecurangan yang dilakukan perusahaan dalam penyajian laporan keuangannya ataupun dalam praktik manajemen labanya dan mampu mengungkapkan kedalam pendapat auditnya (Luhgiatno, 2008).

Persoalan dalam penelitian ini yaitu pertama, bagaimana pengaruh konvergensi IFRS terhadap manajemen laba. Kedua, bagaimana pengaruh kualitas audit sebagai variabel moderasi terhadap konvergensi IFRS dengan manajemen laba. Tujuan dari penelitian ini yaitu untuk mengetahui pengaruh konvergensi IFRS terhadap manajemen laba dengan kualitas audit sebagai variabel pemoderasi. Hasil dari penelitian ini diharapkan mampu memberikan manfaat bagi stakeholder untuk menjadi evaluasi atas pelaporan keuangan dan informasi akuntansi di Indonesia dan juga bagi otoritas agar dapat memberikan evaluasi atas konvergensi IFRS di Indonesia serta diharapkan dapat memberikan wawasan atau informasi bagi pembaca dan bahan acuan penulisan jurnal selanjutnya. 


\section{KAJIAN PUSTAKA}

\section{Manajemen Laba}

Manajemen laba adalah usaha yang dilakukan oleh manajemen untuk memaksimalkan laba maupun meminimumkan laba yang dapat dilakukan sesuai dengan yang diingkan pihak manajemen. (Luthan, 2016) menyebutkan bahwa manajemen laba adalah untuk memenuhi tujuan pribadi manajemen yang akan melakukan sesuatu untuk memperoleh keyakinan laporan keuangan bagi beberapa pihak untuk proses penentuan laba sedangkan Ahmar, Rokhmania \& Samekto (2016) mendefinisikan manajemen laba merupakan tindakan manajer yang terjadi ketika manajer mengubah laporan keuangan melalui kebijakan laporan keuangan guna meyakinkan stakeholder untuk menunjukkan kualitas laba perusahaan yang baik. Adanya motivasi manajer melakukan manajemen laba dikemukakan oleh (Scott, 2009) yaitu (bonus scheme) bonus, (debt covenant) yang disebut kontrak utang jangka panjang , (political motivation) motivasi politik, (taxation motivation) motivasi pajak, (chief executive officer) CEO, dan (initial public offering) IPO.

Manajemen laba dalam tindakannya juga terdapat pola yang bisa dijelaskan oleh manajer yaitu: (1) Taking a bath yaitu nilai yang sangat rendah atau nilai yang sangat tinggi yang dilaporkan sebagai laba periode berjalan, (2) Income masimazation yaitu dapat disebut sebagai laba periode berjalan dilaporkan lebih rendah dari yang semestinya, (3) Income minimization adalah laba pada periode berjalan dilaporkan dengan lebih tinggi dari yang semestinya, (4) Income smoothing adalah yang laba berfluktuasi pada periode yang telah ditentukan, hal tersebut merupakan pendapat dari (Scott, 2009).

\section{Kualitas Audit}

Behn, Carcello, Hermanson, \& Hermanson (1997) mengungkapkan bahwa kualitas audit yang baik mampu membawa investor dalam pengambilan keputusan yang tepat serta meningkatkan nilai mutu dari laporan keuangan. Kualitas audit mampu mendeteksi kesalahan dalam laporan keuangan perusahaan semakin berkualitas auditor akan mampu mencegah dan mengendalikan kesalahan-kesalahan praktik-praktik akuntansi. Menurut Ikatan Akuntan Indonesia (IAI) jika sesuai dengan standar mutu Auditor akan lebih berkualitas dan menyesuaikan juga dengan standar auditing, dalam hal ini kualitas audit yang bernilai tinggi akan sangat mempengaruhi bagaimana pelaporan keuangan disajikan dengan sesuai standar yang ada dan mendeteksi manajemen laba pada suatu perusahaan. Perusahaan juga mempengaruhi kualitas audit dalam hal ini audit Big 4 memiliki kualitas yang lebih tinggi apabila dibandingkan dengan perusahaan yang auditnya non Big 4 (Francis \&Schipper, 1999).

\section{Penerapan IFRS di Indonesia}

IFRS adalah suatu standar pelaporan yang berguna untuk mengatasi permasalahan standar-standar yang ada di banyak negara, karena setiap perusahaan yang multinasional akan memerlukan suatu standar yang bisa diterapkan pada seluruh negara dalam penerapan akuntansi Internasional. Indonesia mulai menerapkan IFRS menurut Dewan Standar Akuntansi Keuangan (DSAL-IAI) mulai 
tahun 2009 dan masih berlanjut hingga tahun 2012 untuk PSAK direvisi agar material dan mulai berlaku efektif pada tahun 1 Januari 2012. Konvergensi banyak ditemukan pada negara berkembang seperti Indonesia, penerapan konvergensi IFRS di Indonesia dilakukan bertahap yaitu mengganti standar nasionalnya dan berpedoman pada IFRS. Menurut Handayani (2014) terdapat manfaat dalam penerapan konvergensi IFRS yaitu (1) kualitas standar akuntansi akan meningkat, (2) akan mengurangi biaya SAK (3) kegunaan laporan keuangan akan meningkat dan juga kredibilitasnya (4) transparansi keuangan akan meningkat (5) biaya modal akan turun melalui bantuan pasar modal jika mampu mengungkapkan peluang (6) penyusunan laporan keuangan akan lebih efisien.

\section{Perumusan Hipotesis}

\section{Pengaruh Konvergensi IFRS terhadap Manajemen Laba}

Laporan keuangan sebaiknya diungkapkan sejalan dengan informasi yang ada dan diungkapkan sebagai keputusan yang digunakan oleh manajemen, sehingga mencerminkan laporan keuangan yang sesuai dengan informasi yang ada, apabila terdapat informasi yang tidak seimbang atau terdapat kesenjangan informasi maka akan menimbulkan tindakan manajemen laba.

Penelitian yang telah dilakukan Kurniawati (2011) Konvergensi IFRS berpengaruh negatif terhadap manajemen laba, dalam penelitian tersebut menunjukan bahwa penerapan standar akuntansi IFRS terjadi penurunan manajemen laba setelah perusahaan menerapkan standar IFRS. Menurut Qomariah \& Marsono (2013) dengan diterapkannya IFRS akan menurunkan manajemen laba dengan adanya pembatasan pertimbangan akibatnya penerapan konvergensi IFRS akan membuat kebijakan manajemen yang semakin sedikit dalam pemilihan metode akuntansi. Penelitian yang dilakukan oleh Handayani (2014) mengungkapkan jika adopsi IFRS menurunkan tingkat manajemen laba. Berdasarkan penjelasan diatas maka dapat dirumuskan hipotesis, sebagai berikut:

H1: Konvergensi IFRS berpengaruh negatif terhadap manajemen laba.

\section{Pengaruh Kualitas Audit sebagai Variabel Moderasi terhadap hubungan Konvergensi IFRS dengan Manajemen Laba}

Stakeholder akan mempercayai laporan keuangan yang telah diaudit oleh Auditor yang memiliki kualitas yang tinggi karena dianggap akan lebih mampu mendeteksi setiap kejanggalan dalam pelaporan keuangan dengan lebih berhati-hati mendeteksi salah saji material. IFRS dianggap mampu membuat laporan keuangan menjadi semakin berkualitas. IFRS dianggap mampu membatasi kekuasaan manajemen dalam hal memanipulasi laba. Kualitas audit akan membawa pengaruh konvergensi IFRS terhadap manajemen laba.

Menurut penelitian yang dilakukan oleh Kurniawati (2011) menyatakan jika kualitas audit yang baik dimana auditor yang berkualitas akan berhati-hati dalam mendeteksi salah saji dan membatasi keleluasaan manajemen untuk memanipulasi laba. Dalam penjabaran Christiani \& Nugrahanti (2014) menyatakan jika auditor akan mampu mendeteksi manajemen laba yang besar dan akan dibatasi oleh kemampuan Auditor yang bekerja di KAP Big Four sehingga informasi akan lebih berkualitas dan meningkatkan kualitas pelaporan keuangan yang ditinjau oleh IFRS. IFRS akan mampu 
membatasi kekuasaan manajemen dalam memanipulasi laba dengan adanya kualitas audit yang baik yang mampu memperkuat pengaruh konvergensi IFRS terhadap manajemen laba. Berdasarkan penjelasan diatas maka dapat dirumuskan hipotesis, sebagai berikut:

H2: Kualitas Audit memperkuat hubungan antara konvergensi IFRS terhadap manajemen laba.

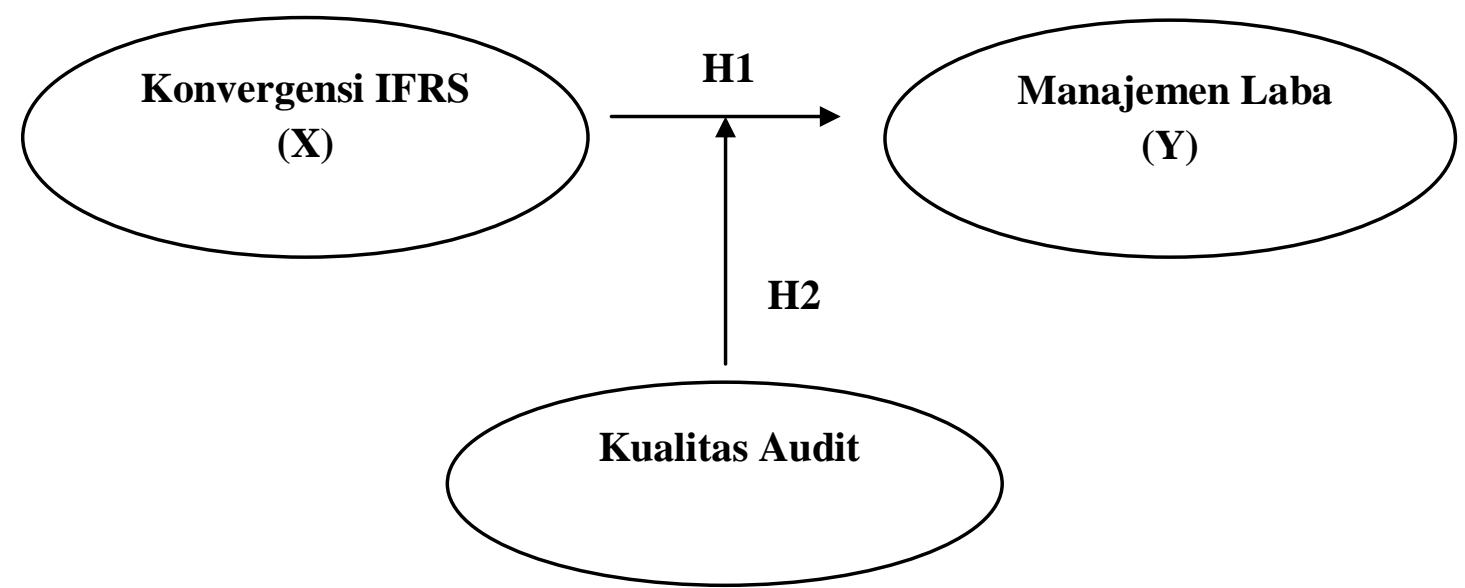

Gambar 1. Model Penelitian

\section{METODE PENELITIAN}

Jenis penelitian dalam penelitian ini adalah penelitian kuantitatif. Penelitian ini bertujuan untuk menganalisis hubungan antara satu variabel dengan variabel lainnya. Dalam penelitian ini menggunakan data sekunder yaitu data yang bersumber dari Bursa Efek Indonesia. Data yang digunakan dalam penelitian ini yaitu data cross section (data panel) dengan data yang digunakan berupa informasi laba bersih dan arus kas operasi pada perusahaan-perusahaan manufaktur tahun 2008-2018.

Populasi dalam penelitian ini adalah Perusahaan Manufaktur yang terdaftar di BEI selama 2008-2018. Teknik pengambilan sampel dalam penelitian ini yang dengan metode purposive sampling dengan kriteria yaitu: (1) Perusahaan Manufaktur yang listing di Bursa Efek Indonesia periode 2008-2018; (2) Perusahaan yang memiliki data penelitian yang lengkap; (3) Laporan keuangan yang disajikan dalam mata uang Rupiah; (4) Perusahaan yang tidak mengalami kerugian selama periode penelitian 2008-2018; (5) Perusahaan memiliki periode laporan keuangan yang telah di audit dan berakhir pada 31 Desember.

Konvergensi IFRS merupakan variabel independen dalam penelitian ini, terdapat beberapa kriteria yang digunakan dalam pengukuran variabel ini menggunakan variabel dummy, yaitu nilai 0 untuk adopsi IFRS pada tahun tahap pertama, nilai 1 untuk tahun tahap persiapan IFRS, dan 2 untuk tahun pada tahap implementasi IFRS. Variabel dependen dalam penelitian ini manajemen laba merupakan variabel dependen model perhitungannya diukur dengan discretionary accruals menggunakan Modified Jones Tait = Nit-CFOit 
Nilai total accrual yang diestimasi dengan persamaan regresi OLS sebagai berikut:

Tait/Ait-1 = a1 $(1 /$ Ait-1 $)+\beta 1(\Delta$ Reci $/$ Ait-1 $)+\beta 2($ PPEt/Ait-1 $)+e$

Dari persamaan regresi diatas, NDA dapat dihitung dengan rumus:

NDAit $=a 1(1 /$ Ait-1) $+\beta 1(\Delta$ Salesit/Ait-1- $\Delta$ Recit/Ait-1 $)+\beta 2(P P E t / A i t-1)$

Selanjutnya DA dapat dihitung sebagai berikut:

DAit $=($ Tait/Ait -1$)-N D A i t$

\section{Keterangan :}

DAit

: Discreationary Accruals perusahaan i pada periode $t$

NDAit $\quad$ : Non Discreationary Accruals perusahaan i periode $\mathrm{t}$

TAit $\quad:$ Total Accruals perusahaan i pada periode $\mathrm{t}$

Nit $\quad$ : Laba bersih perusahaan i pada periode ke-t

CFOit : : Aliran kas dari aktivitas perusahaan i pada periode $t$

Ait-1 : Total aktiva perusahaan i pada periode $\mathrm{t}$

$\triangle S A L E S i t \quad$ : Selisih sales perusahaan i pada periode $\mathrm{t}$

$\triangle$ Recit $\quad$ : Perubahan piutang perusahaan i pada periode $\mathrm{t}$

PPEt : Nilai aktiva tetap (gross) perusahaan i pada periode $\mathrm{t}$

e : error

Variabel moderasi merupakan suatu variabel yang memperkuat dan memperlemah variabel lain (Saputra, 2015). Kualitas audit merupakan variabel moderasi dalam penelitian ini variabel ini diukur menggunakan dummy dimana skor yang digunakan adalah 1 untuk perusahaan yang diaudit oleh KAP Big 4 dan 0 untuk perusahaan yang diaudit oleh KAP Non Big 4.

Teknik Analisis Data

Gabungan data time series dan cross section merupakan data panel, dalam menggabungkan informasi data time series dan juga cross section dapat mengatasi suatu masalah apabila terdapat masalah penghilangan variabel. Model regresi yang digunakan dalam penelitian ini yaitu:

$$
E M=\alpha+\beta 1 \text { IFRS }+\beta 2 \text { Auditi }+\beta 3 \text { IFRS * Audit } i+\varepsilon
$$

\section{Keterangan:}

$E M \quad=$ Earning Management

a $\quad=$ Konstanta

$\beta 1-\beta 3=$ Koefisien Regresi

IFRS $=$ Konvergensi IFRS

Auditi $=$ Kualitas Audit

IFRS* Auditi = Interaksi antara Konvergensi IFRS dengan Kualitas Audit

$\varepsilon=$ Disturbance error (faktor pengganggu/ residual)

Terdapat 3 pemilihan model yang digunakan: (1) Uji Chow Test. Untuk mengetahui apakah teknik regresi data panel dengan model fixed effect lebih baik dari regresi model data panel tanpa variabel dummy atau model common effect. Model fixed 
effect dipilih apabila $\mathrm{f}$ hitung lebih besar daripada $\mathrm{f}$ kritis. Sedangkan model common effect dipilih ketika f kritis lebih besar dari pada f hitung, (2) Uji Hausman Test. Uji yang dilakukan untuk mengetahui apakah teknik regresi data panel dengan model fixed effect lebih baik dari regresi model data panel dengan model random effect, dan (3) Uji Langrangge Multiple. Uji yang dilakukan untuk mengetahui apakah teknik regresi data panel dengan model common effect lebih baik dari regresi model data panel dengan model random effect.

\section{HASIL DAN PEMBAHASAN Statistik Deskriptif}

Studi ini menggunakan 473 perusahaan yang terdaftar di BEI sebagai data cross section, selama sebelas tahun mulai tahun 2008 sampai dengan 2018 sebagai data time series. Data dalam penelitian ini terdiri dari earning management (EM) sebagai variabel terikat, International Financial Reporting Standards (IFRS) sebagai variabel bebas, Kualitas Audit(Auditi) sebagai variabel moderasi. Tabel analisis deskriptif berikut ini bertujuan untuk menyajikan gambaran dari variabel-variabel penelitian yang diolah menggunakan aplikasi EViews versi 10.

Earning Management digunakan dalam penelitian untuk mengukur variabel manajemen laba sebagai variabel dependen berdasarkan hasil analisis deskriptif di atas, dapat dilihat bahwa nilai maksimum dari variabel EM adalah 2,431590 dan nilai minimum adalah 3,29000. Nilai rata-rata (mean) sebesar 5,545702. Hal ini menunjukkan bahwa nilai pada manajemen laba tidak melihat kearah positif maupun negatif dan dengan standar deviasi 3,045233 menunjukkan penyimpangan terjadinya terhadap manajemen laba sebesar 3\%.

Tabel 1. Statistik Frekuensi

\begin{tabular}{|c|c|c|}
\hline Nilai & Jumlah & $\begin{array}{l}\text { Prosentas } \\
\text { e }\end{array}$ \\
\hline \multicolumn{3}{|c|}{ Panel A. Variabel IFRS } \\
\hline 0 & 172 & 36.36 \\
\hline 1 & 301 & 63.64 \\
\hline Total & 473 & 100.00 \\
\hline \multicolumn{3}{|c|}{ Panel B. Variabel Audit } \\
\hline 0 & 224 & 47.36 \\
\hline 1 & 249 & 52.64 \\
\hline Total & 473 & 100.00 \\
\hline
\end{tabular}

IFRS diukur menggunakan dummy variable, 0 jika perusahaan 2008-2011 dan 1 untuk perusahaan 2012 keatas. Sampel yang telah menerapkan IFRS sebanyak 301 sampel dan yang belum menerapkan IFRS sebanyak 172 sampel sedangkan untuk presentase perusahaan yang belum menerapkan IFRS sebesar 36,3 \% dan yang telah menerapakan IFRS sebesar 63,6 \%.

Auditi diukur menggunakan dummy variable, 0 jika perusahaan menggunakan Akuntan Publik Non Big Four dan 1 jika perusahaan menggunakan Akuntan Publik Big Four. Sampel yang menggunakan akuntan publik Non Big Four sebanyak 224 sampel 
dan yang menggunakan Akuntan Publik Big Four sebanyak 249. Presentase yang menggunakan Non Big Four sebesar 47,3\% dan presentase yang menggunakan Big Four sebesar $52,6 \%$.

\section{Uji Stasioneritas}

Uji stasioneritas merupakan syarat yang harus dilakukan ketika akan mengolah data panel menggunakan EViews. Asumsi stasioneritas adalah hal yang harus dipenuhi ketika melakukan analisis time series dan cross section. Suatu data pengamatan dikatakan stasioner apabila prosesnya tidak mengalami perubahan seiring dengan waktu yang berubah atau nilai rata-rata dan varian dari data tersebut. Pada penelitian ini uji stasioneritas dilakukan menggunakan uji unit root. Pengujian tingkat stasioneritas data menggunakan levin, lin $\mathcal{E}$ chu (LLC) untuk pengujian stasioneritas secara keseluruhan dan augmented dickey fuller (ADF) untuk pengujian stasioneritas masing-masing observasi. Data dianggap stasioner apabila nilai probabilitasnya kurang dari 0,05, dan dianggap tidak stasioner ketika nilai probabilitasnya diatas 0,05 . Berikut merupakan hasil uji unit root dari masing-masing data penelitian.

Tabel 2. Hasil Uji Unit Root

\begin{tabular}{lcccc}
\hline \multicolumn{1}{c}{ Variabel } & \multicolumn{2}{c}{ Levin, Lin \& Chu t* } & \multicolumn{2}{c}{ ADF - Fisher Chi-square } \\
\hline & Statistic & Prob. & Statistic & Prob. \\
EM & $-4,84993$ & $0,0000^{*}$ & 190.434 & $0,0000^{*}$ \\
IFRS & $-5,87315$ & $0,0000^{*}$ & 109,237 & $0,0462^{*}$ \\
Auditi & $-2,48157$ & $0,0065^{*}$ & 8,37002 & $0,0152^{*}$ \\
IFRS*Auditi & $-4,19965$ & $0,0000^{*}$ & 75,9261 & $0,0036^{*}$ \\
\hline
\end{tabular}

Melalui tabel hasil uji unit root untuk variabel EM, nilai probabilitas uji levin, lin $\mathcal{E}$ chu menunjukkan angka sebesar $0,0000<0,05$, kemudian probabilitas dari uji augmented dickey fuller 0,0000 < 0,05. Berdasarkan nilai tersebut dapat disimpulkan bahwa data dari variabel EM merupakan stasioner pada tingkat $1^{\text {st }}$ difference . Kemudian untuk tabel hasil uji unit root untuk variabel IFRS, nilai probabilitas uji levin, lin $\mathcal{E}$ chu menunjukkan angka sebesar 0,0000 < 0,05, kemudian probabilitas dari uji augmented dickey fuller 0,0462 < 0,05. Berdasarkan nilai tersebut dapat disimpulkan bahwa data dari variabel IFRS merupakan stasioner pada tingkat $1^{\text {st }}$ difference $l$.

Pada tabel hasil uji unit root untuk variabel Auditi, nilai probabilitas uji levin, lin $\mathcal{E}$ chu menunjukkan angka sebesar 0,0065 < 0,05 kemudian probabilitas dari uji augmented dickey fuller 0,0152 < 0,05. Berdasarkan nilai tersebut dapat disimpulkan bahwa data dari variabel Auditi merupakan stasioner pada tingkat $1^{\text {st }}$ difference. Sedangkan untuk variabel IFRS*Audit melalui tabel hasil uji unit root, nilai probabilitas uji levin, lin $\mathcal{E}$ chu menunjukkan angka sebesar 0,0000 <0,05, kemudian probabilitas dari uji augmented dickey fuller 0,0036 < 0,05. Berdasarkan nilai tersebut dapat disimpulkan bahwa data dari variabel IFRS*Auditi merupakan stasioner pada tingkat $1^{\text {st }}$ difference.

Pengukuran yang digunakan untuk menentukan model regresi data panel yang paling tepat melalui uji statistik $\mathrm{f}$ (uji chow) adalah dengan melihat nilai probabilitas dari cross-section $f$, kemudian bandingkan dengan derajat signifikansi sebesar 0,05. Apabila nilai probabilitas cross-section $f$ kurang dari 0,05 maka dapat disimpulkan bahwa model fixed effect adalah model yang paling tepat daripada model common effect. 
Melalui tabel diatas karena nilai probabilitas dari cross-section $f$ sebesar 0,0000 yang nilainya kurang dari derajat signifikansi sebesar 0,05 , maka dapat disimpulkan untuk penelitian ini model fixed effect lebih tepat untuk digunakan dibandingkan dengan model common effect.

Tabel 3. Hasil Uji Model Regresi

\begin{tabular}{|c|c|c|c|}
\hline \multicolumn{4}{|c|}{ Panel A: Uji Statistik F (Uji Chow) } \\
\hline Effects Test & Statistic & Prob. & Result \\
\hline Cross-section F & 4,479058 & 0,0000 & \multirow{2}{*}{ Fixed Effect } \\
\hline Cross-section Chi-square & 172,661129 & 0,0000 & \\
\hline \multicolumn{4}{|l|}{ Panel B: Uji Hausman } \\
\hline Test Summary & Chi-Sq. Statistic & Prob. & Result \\
\hline Cross-section random & 0,577868 & 0,9015 & lom Effect \\
\hline \multicolumn{4}{|c|}{ Panel C: Uji Lagrange Multiplier } \\
\hline Null Alternative & Periode- one sided & Prob & Result \\
\hline Breusch Pegan & 0,0130 & 0,0000 & Fixed Effect \\
\hline
\end{tabular}

Pada uji hausman yang digunakan sebagai penentu model regresi data panel yang akan digunakan dalam penelitian adalah dengan melihat nilai probabilitas dari crossrandom, kemudian bandingkan dengan derajat signifikansi sebesar 0,05. Apabila nilai probabilitas cross-random kurang dari 0,05 maka dapat disimpulkan bahwa model fixed effect adalah model yang paling tepat daripada model common effect. Melalui tabel diatas karena nilai probabilitas dari cross-random sebesar 0,9997 yang nilainya lebih dari derajat signifikansi sebesar 0,05 .

Pengujian lagrange multiplier (LM) perlu dilakukan karena melalui hasil uji statistik $\mathrm{f}$ (uji chow) dan uji hausman, keduanya menyimpulkan bahwa model fixed effect dan random effect adalah model yang tepat dibandingkan dengan model common effect maka perlu uji LM untuk menentukan model yang paling tepat setelah dilakukan uji Lagrange Multiplier nilai Probabilitas menunjukan kurang dari 0,05 maka digunakan uji fixed effect. Melalui ketiga pengujian maka dapat disimpulkan uji fixed effect yang tepat digunakan sebagai metode yang paling tepat.

\section{Hasil Uji Hipotesis}

Pengujian dilakukan dengan membandingkan tingkat probabilitas dengan derajat signifikansi sebesar 0,05. Variabel bebas dan Variabel moderasi berpengaruh signifikan terhadap variabel terikat apabila tingkat probabilitas kurang dari 0,05.

\section{Tabel 4. Hasil Uji T}

\begin{tabular}{ccc}
\hline Variable & Coefficient & Prob \\
\hline IFRS & $-1,007828$ & 0,0061 \\
Auditi & $-7,300932$ & 0,5418 \\
IFRS*Auditi & 1,266565 & 0,8030 \\
C & 6,614767 & 0,0000 \\
\hline R-squared & 0,327132 & \\
Adjusted R-squared & 0,256221 & \\
\hline
\end{tabular}


Nilai probabilitas dari variabel IFRS adalah $0,0061<\alpha$ 0,05 dengan nilai coefficient regresi $(-1,007828)$ memiliki arti jika IFRS berpengaruh secara negatif dan signifikan terhadap EM atau Manajemen Laba. Kemudian untuk probabilitas variabel Kualitas Audit atau Auditi bernilai 0,5418 dan nilai coefficient regresi $(-7,300932)$ memiliki arti jika kualitas audit berpengaruh negatif dan tidak signifikan terhadap manajemen laba . kualitas audit tidak memiliki dampak terhadap manajemen laba.

Uji koefisien determinasi merupakan pengujian yang dilakukan untuk mengetahui baik atau tidaknya model regresi yang terestimasi. Pengujian ini menggunakan nilai adjusted $r$-squared dalam menilai tingkat baik atau tidaknya model regresi yang digunakan. Nilai koefisien determinasi berada diantara angka 0 dan 1 , apabila hasil pengujian mendekati angka 0 maka kemampuan variabel-variabel bebas dalam menjelaskan variabel terikat dinilai rendah atau terbatas. Tetapi jika hasil pengujian mendekati angka 1 maka variabel-variabel bebas penelitian dianggap dapat menjelaskan variabel bebas secara keseluruhan. Berdasarkan hasil uji koefisien determinasi, didapat nilai adjusted $r$-squared sebesar 0,256221. Nilai tersebut memiliki arti bahwa IFRS dan Auditi dapat menjelaskan EM sebesar 25\%, sedangkan sisanya dipengaruhi oleh variabel lain diluar penelitian ini. Dapat disimpulkan bahwa model regresi cukup baik karena mampu menjelaskan data aktualnya.

\section{Analisis dan Pembahasan}

Hasil penelitian ini, ditemukan jika hipotesis pertama diterima dan dapat disimpulkan bahwa dengan adanya Konvergensi IFRS dapat menurunkan praktik manajemen laba pada perusahaan manufaktur yang terdaftar di Bursa Efek Indonesia. Menurut Rohaeni \& Aryati, (2012) Konvergensi IFRS di Indonesia dapat menurunkan tingkat praktik manajemen laba. Hubungan negatif ini diduga karena penerapan IFRS sebagai standar global akan berdampak pada semakin sedikitnya pilihan metode akuntansi yang dapat diterapkan sehingga akan memperkecil praktik-praktik kecurangan akuntansi dan IFRS mengharuskan setiap komponen laporan keuangan untuk melakukan pengungkapan penuh (full disclosure). Dengan adanya full disclosure, manajemen akan berhati-hati ketika melakukan tindakan dalam melakukan praktek manajemen laba sehingga menghasilkan informasi laporan keuangan yang jujur dan informatif. Fleksibilitas ketika memilih metode akuntansi kadang-kadang memotivasi manajer untuk memilih metode akuntansi atau untuk mengubah yang digunakan dalam rangka meningkatkan, menurunkan atau meratakan angka pendapatan dari tahun ke tahun.

Berdasarkan hasil analisis statistik dalam penelitian ini, ditemukan bahwa hipotesis kedua ditolak dan dapat disimpulkan bahwa dengan adanya kualitas audit belum mampu meningkatkan hubungan konvergensi IFRS dengan praktek manajemen laba. Pengaruh kualitas audit terhadap hubungan konvergensi IFRS dengan manajemen laba ditentukan dengan menginteraksikan variabel konvergensi IFRS dengan variabel kualitas audit dengan proksi reputasi kantor akuntan publik. Dengan menginteraksikan kedua variabel tersebut dihasilkan temuan bahwa dengan adanya kualitas audit pengaruh konvergensi IFRS terhadap manajemen laba menjadi semakin lemah, semakin lemahnya interaksi kualitas audit dan konvergensi IFRS maka praktek manajemen laba juga semakin meningkat. Hal ini terjadi diduga karena hambatan dari 
pihak manajemen perusahaan yang secara sengaja maupun tidak sengaja menutupi suatu fakta yang harusnya diberikan kepada auditor. Namun hal ini dapat juga terjadi karena faktor sumber daya manusia yang terdapat dalam KAP tersebut. Kuantitas dan kualitas auditor sangat mempengaruhi hasil pekerjaannya, namun bukan berarti bahwa KAP big 4 memiliki sumber daya manusia lebih baik dari KAP non big 4 , karena baik atau buruknya kualitas seorang auditor tidak ditentukan dari besarnya KAP yang menaunginya, namun ditentukan dari dan oleh diri auditor itu sendiri. Sedangkan faktor lain seperti pada saat periode penelitian diduga banyak perusahaan yang sedang melakukan event-event tertentu sehingga perusahaan cenderung mempercantik laporan keuangannya, atau adanya audit failures. Audit failures terjadi ketika auditor menyatakan opini audit yang salah karena pelaksanaan audit tidak sesuai dengan standar auditing (Rohaeni \& Aryati, 2012).

\section{KESIMPULAN DAN SARAN}

Penelitian ini bertujuan untuk melihat apakah konvergensi IFRS pada perusahaan manufaktur yang terdaftar di PT. Bursa Efek Indonesia (BEI) pada tahun 2008 sampai dengan tahun 2018 dapat mempengaruhi manajemen laba dengan kualitas audit sebagai variabel moderasi. Berdasarkan hasil temuan penelitian dan pengujian hipotesis yang diajukan sebelumnya dapat disimpulkan bahwa Konvergensi IFRS berpengaruh negatif terhadap tindakan manajemen laba dan Dengan adanya kualitas audit, memperlemah hubungan konvergensi IFRS terhadap praktik manajemen laba dalam hal ini menunjukkan jika IFRS dalam setiap komponennya mengharuskan pengungkapan secara penuh dan membuat manajer harus memilah metode akuntansi dalam meningkatkan pendapatan. Kualitas Audit tidak berpengaruh karena hambatan dari pihak manajemen perusahaan dalam pengungkapan fakta kepada Auditor.

Bagi peneliti selanjutnya lebih baik menggunakan lebih banyak PSAK yang sudah bersifat konvergen terhadap IFRS.Bagi pihak akademik untuk lebih menjelaskan kepada mahasiswa mengenai IFRS di Indonesia, sehingga mahasiswa lebih memahami bagaimana fenomena IFRS di Indonesia. Peneliti selanjutnya, diharapakan mempelajari lebih dalam model perhitungan penerapan IFRS, sehingga lebih memahami bagaimana mengukur penerapan IFRS di Indonesia. Peneliti hanya mengambil sampel tahun pengamatan hingga tahun 2018 saja, jadi diharapkan untuk penelitian berikutnya bisa melakukan penelitian hingga setelah tahun pengamatan 2018.

\section{TINJAUAN PUSTAKA}

Ahmar, N., Rokhmania, N. \& Samekto, A. (2016). Model Manajemen Laba Akrual dan Rill Berbasis Implementasi Internasional Financial Stndards. Jurnal Akuntansi Dan Investasi, 17 (1), 79-92. doi: 10.18196/jai.2016.0046. 7

DeAngelo, L.E. (1981). Auditor Size and Auditor Quality. Journal of Accounting and Economics, 3, 183-199. doi: 10.1016/0165-4101(81)90002-1

Behn, B. K., Carcello, J.V., Hermanson, D. R. \& Hermanson R. H. (1997).The Determinants of Audit Client Satisfaction Among Clients of Big 6 Firms. Accounting Horizons, Available at: http://works.bepress.com/joseph_carcello/25/ 
Cahyati, A.D., (2010). Implikasi Tindakan Perataan Laba terhadap Pengambilan Keputusan. Jurnal Riset Akuntansi Dan Komputerisasi Akuntansi, 1 (2), 70-86. doi: 10.33558/jrak.v1i2

Chen, H., Tang, Q., Jiang, Y. \& Lin, Z. (2010). The Role of International Financial Reporting Standards in Accounting Quality: Evidence from the European Union. Journal of International Financial Management \& Accounting, 21 (3), 220-278. doi:10.1111/j.1467-646X.2010.01041.x

Christiani, I. \& Nugrahanti,Y.W. (2014). Pengaruh Kualitas Auditor terhadap Manajemen Laba. Jurnal Akuntansi dan Keuangan, 16 (1), 52-62. doi: 10.9744/jak.16.1.52-62

Dimitropoulos,P.E., Asteriou, D., Kousenidis.,D. \& Leventis, S. (2013). The Impact of IFRS on Accounting Quality: Evidence from Greece. Advances in Accounting, 29 (1), 108-123.doi: 10.1016/j.adiac.2013.03.004

Francis, J. \& Schipper, K. (1999). Have Financial Statement Lost Their Relevance. Journal of Accounting Research, 37 (2), 319-352

Handayani. (2014). Analisis Perbedaan Manajemen Laba Sebelum dan Sesudah Penerapan Standar Akuntansi Keuangan. Jurnal Akuntansi, 2(1), 1-10

Kabir, M.H. \& Laswad, F. (2011). Properties of Net Income and Total Comperhensive Income. Accounting Research Journal, 24(3), 268-289. doi: $\underline{10.1108 / 10309611111187000}$

Kurniawati, N. (2011). Pengaruh Tingkat Pengungkapan Laporan Keuangan Terhadap Manajemen Laba Dengan Kualitas Audit Sebagai Variabel Pemoderasi. Magister Thesis Universitas Brawijaya Malang.http://repository.ub.ac.id/id/eprint/159147

Luhgiatno. (2008). Analisis Pengaruh Kualitas Audit Terhadap Manajemen Laba : Studi Pada Perusahaan yang melalkukan IPO di Indonesia. Thesis Magister Sains Akuntansi Universitas Diponegoro

Luthan. (2016). The effect of Good Corporate Governance Mechanism to Earnings Management Before and After IFRS Convergence. Procedia-Social and Behavioral Sciences, 219, 465-471.

Narendra, A. \& Haryanto, H. (2013). Pengaruh Pengadopsian Internasional Financial Reporting Standar (IFRS) Terhadap Manajemen Laba (Studi Empiris Pada Perusahaan Manufaktur Yang Terdaftar Di Bursa Efek Indonesia Pada Tahun 2011 - 2012). Diponegoro Journal of Accounting, 2 (4), 1-10

Nurhayanto. (2010). International Financial Reporting Standards (IFRS) : Konvergensi dan Kendala Implementasi di Indonesia. Pusdiklatwas BPKP, Ciawi, 12.

Permata, S.I., Muslim, R.Y., Fauziati, P. (2015). Pengaruh Konvergensi IFRS terhadap Manajamen Laba Dengan Perlindungan Investor sebagai Variabel Pemoderasi. Jurnal Departemen Ilmu Ekonomi, 6 (1),1-13

Qomariah, R.N.\& Marsono, M. (2013). Dampak Konvergensi IFRS terhadap Manajemen Laba dengan Struktur Kepemilikan Manajerial sebagai Variabel Moderating. 
Diponegoro Journal of accounting, 2 (4), 1-11

Rohaeni, D. \& Aryati, T. (2012). Pengaruh Konvergensi IFRS terhadap Income Smoothing dengan Kualitas Audit sebagai Variabel Moderasi. Simposium NasionalAkuntansi Banjarmasin

Rusmin, R. (2010). Auditor Quality and Earnings Management: Singaporean Evidence. Managerial Auditing Journal, 25 (7), 618-638. doi: 10.1108/02686901011061324

Santy \& Pontoh. (2012). Pengaruh Adopsi IFRS Terhadap Manajemen Laba pada Perusahaan Perbankan di Bursa Efek Indonesia. Workingpaper Fakultas Ekonomi Universitas Hasanuddin.

Saputra, A. (2015). Pengaruh Konvergensi IFRS terhadap Income Smoothing dengan Kualitas Audit Sebagai Variabel Moderasi (Studi pada perusahaan manufaktur yang terdaftar di BEI tahun 2008-2012) Jurnal Akuntansi, 3 (1), 1-10.

Scott. (2009). Financial Accounting Theory.Fift Edition, Prentice Hall, USA. 